- ORIGINAL ARTICLE

Volume 10 Issue 12018

DOI: 10.21315/eimj2018.10.1.6

ARTICLE INFO

Submitted: $10-01-2018$

Accepted: 21-02-2018

Online: 30-03-2018

\section{Evaluation of an Interprofessional Course on Leadership and Management for Medical and Nursing Pre-registration House Officers}

\author{
Asmaa Abdel Nasser El Bakry ${ }^{1}$, Amira Farghaly ${ }^{1,2}$, Mohamed Hany \\ Shehata ${ }^{3}$, Amgad Matter', Somaya Hosny \\ ${ }^{1}$ The Faculty of Medicine, Suez Canal University, Ismailia, EGYPT \\ ${ }^{2}$ Prince Sattam Bin Abdulaziz University, College of Medicine, \\ Al Kharj, SAUDI ARABIA \\ ${ }^{3}$ Department of Family Medicine, Helwan University, Helwan, EGYPT
}

To cite this article: Abdel Nasser El Bakry A, Farghaly A, Shehata MH, Matter A, Hosny S. Evaluation of an interprofessional course on leadership and management for medical and nursing pre-registration house officers. Education in Medicine Journal. 2018;10(1):43-54. https://doi. org/10.21315/eimj2018.10.1.6

To link to this article: https://doi.org/10.21315/eimj2018.10.1.6

\begin{abstract}
Interprofessional education is about two or more professions learning from, with, and about each other, for the aim of better working together in the future. The aim of this study is to evaluate the outcomes of an interprofessional course on management and leadership for medical and nursing pre-registration house officers. Thirty eight house officers were enrolled in the course on an elective basis. The course comprised three workshops in addition to a collaborative project. Evaluation of the outcomes of the course followed Hammick's four-level model for evaluation of interprofessional education. The participants completed course evaluation questionnaires in addition to a readiness questionnaire administered before and after the implementation of the course. Knowledge acquisition was measured by a paper and pencil test. Acquisition of skills in leadership and management was assessed by the evaluation of the projects. Changes in participants' behaviour towards interprofessional collaboration were evaluated by supervisors, nurses, and colleagues. The $t$-test was used to compare between the results of the pre- and post-tests for assessment of knowledge. It was also used to compare the readiness of the participants, as well as the multi-source feedback about their collaborative attitude before and after the course. Statistical significant improvement was observed in the participants' readiness for interprofessional education, their knowledge in leadership and management, their application of leadership and management skills, as well as their collaborative behaviour at the workplace. The study concluded that the interprofessional course improved the participants' readiness towards interprofessional education, as well as their knowledge, skills, attitudes, and behaviours.
\end{abstract}

Keywords: Interprofessional education, Evaluation, Leadership, Management, Pre-registration

Dr. Amira Farghaly, Medical Education Department, Faculty of Medicine, Suez Canal University, Round Road 41111, Ismailia, Egypt | Emails: amira.medfomscu@gmail.com / am.farghaly@psau.edu.sa 


\section{INTRODUCTION}

In its simplest sense, interprofessional education in medical practice means two or more health professions learning from, with, and about each other, to enable effective collaboration and improve health outcomes $(1,2)$. The focus of interprofessional education (IPE) is on learning together to promote collaborative practice and better care, rather than simply learning together for whatever reason (3). Interprofessional education and practice in health care have been related to improved patient outcomes, enhanced safety and quality of care (4).

Introduction of IPE learning activities in the pre-registration curriculum can add value to the curriculum, since high-quality interprofessional collaboration must be addressed in this period for the effective delivery of high-quality care for different needs in different contexts (5).

A hierarchy of potential benefits of IPE was developed as a framework for considering its outcomes (6). It is inspired by Kirkpatrick's four-level model of evaluation of educational intervention (7). Hammick's hierarchy came in four levels; learners' reaction (Level 1), modification of attitudes and perceptions (Level 2a), acquisition of knowledge and/or skills (Level 2b), change in behaviour (Level 3 ), change in organisational practice (Level $4 a$ ), and benefits to patients (Level 4b).

There is an increasing interest in IPE all over the world. In the UK, several regulatory bodies introduced IPE into their policies, guidelines and requirements. These include the General Medical Council (GMC), the Health Professions Council (HPC), the Nursing and Midwifery Council (NMC), and the General Social Care Council (GSCC) (8). Also, the Quality Assurance Agency (QAA) in UK recommended IPE to be offered by UK universities for all prequalifying health and social care students (9).

In Australia, several government policy documents have advocated for the inclusion of IPE in health professional education programs (10). The Australian Interprofessional Practice and Education Network (AIPPEN) brought together individuals, groups and institutions with an interest in IPE across Australia and New Zealand to promote better health care outcomes through interprofessional education (11).

In 2007, The Canadian Interprofessional Health Collaborative (CIHC) was established in Canada with the mission of advancing interprofessional education and research in order to promote collaborative patient-centered care (12).

In the Middle East, interprofessional education still has little attention from either health or higher education institutions. The reason might be the lack of the educational setting for implementing IPE or the deficiency of the health professions education curricula in addressing IPE (13).

In Egypt, the National Authority for Quality Assurance and Accreditation in Education (NAQAAE) has emphasised IPE by including it in the draft of the second edition of the Egyptian National Academic Reference Standards (NARS) in Medicine, which was developed by NAQAAE to serve as a competency framework for medical graduates. The draft included learning outcomes pertaining to interprofessional collaboration among the competency area "the graduate as a member of the health team and a part of the healthcare system" (14).

The importance of leadership and management in healthcare has become more acknowledged as a result of the increasing complexity of healthcare systems, and the need to link the world of management to the world of medical/clinical practice (15). While management principally focuses on using organisational resources to achieve organisational objectives through management practices, leadership's focus is mainly on inspiring confidence and support among the people who are needed 
to achieve the organisational goals, through communication, motivation, coaching, and team development (16). Recently, the concept of "managers who lead" is gaining more popularity, with application of both management and leadership practices together in harmony in order to face challenges and initiate and sustain change (17).

Since different health professions graduates will eventually work together, it would be beneficial to train them on learning and working collaboratively as early as the preregistration year. Also most of them will practice management and leadership skills during their future professions. Hence this study was designed to evaluate the outcomes of an interprofessional course on management and leadership for medical and nursing house officers to emphasise both IPE and management and leadership concepts and to encourage other health professions institutions to include IPE courses in their official curricula as requested by NAQAAE for the ultimate goal of better healthcare provision.

\section{METHODS}

\section{Study Participants}

Twenty five house-officers and 13 nursing house officers affiliated to Suez Canal University hospital in Ismailia, Egypt, from both genders were enrolled to the study, and were divided into six interprofessional groups (5-8 members per group). Two rotations in the pre-registration year were selected by the course planners; (a) paediatrics, and (b) gynaecology and obstetrics, and registration for the course was open for house officers in these two rotations, both medical and nursing, on an elective basis.

\section{Course Description}

A quasi-experimental single group pretest post-test design was applied in this study, where an interprofessional course on leadership and management was implemented (intervention), and knowledge, skills, attitudes, and behaviours of participants were assessed before and after the course. The pre-intervention data (readiness for IPE, knowledge and skills in leadership and management, and collaborative behaviour) was considered as the "control" for the study group, and was compared to the post-intervention data. All participants received training on leadership and management in a course adapted from the pre-service Leadership Development Program (LDP) by Management Science for Health organisation (MSH) (18). This is a 6-month programme that enables learners to acquire leading and managing practices to face challenges and achieve measurable results in complex conditions. The LDP was adapted into a 2 -month course, preserving the program core competencies (Table 1). The main learning outcomes of the course were to:

a. Identify the leadership and management practices that would enable them to face challenges at the workplace;

b. Develop a shared vision for a certain challenge at the workplace;

c. Construct a Challenge Model that comprises a measurable result, Strengths Weaknesses Opportunities Threats (SWOT) analysis, root cause analysis, priority actions, an action plan and a monitoring plan to face the selected challenge;

d. Use different tools and templates during working on the steps of the Challenge Model;

e. Implement the action plan (collaborative projects);

f. Work collaboratively in interprofessional teams during learning and during implementation of the projects;

g. Acquire a responsible attitude towards the community.

The course was implemented at Suez Canal University hospital in Ismailia, Egypt. The course consisted of three 
highly interactive workshops that included interactive presentations, group discussions and assignments, and lasted collectively for 36 contact hours. In addition to the workshops, the interprofessional teams used leadership and management tools according to the "challenge model" (17) in order to develop collaborative projects to overcome a challenge in hospital departments where they were receiving training as houseofficers. The teams presented their project work in a final seminar that lasted for five hours, where the projects were evaluated by a panel of experts.

The workshops were separated by one week intervals in order to enable the participants to complete the assignments of the course, and work on the activities of the projects. After the third workshop, a period of four weeks was given to participants to complete the implementation of the action plans and finalise the projects.

\section{Data Collection}

To evaluate the outcomes of the course, three of the four levels of Hammick's model (6) were covered in this study. At the first level "Reaction", course evaluation forms were distributed to assess the participants' satisfaction with the course.

Table 1: Course outline

\begin{tabular}{|c|c|c|c|c|}
\hline Content & $\begin{array}{l}\text { Workshop 1: } \\
\text { Introduction and } \\
\text { scanning } \\
\text { 2-day workshop } \\
\text { (12 hours) }\end{array}$ & $\begin{array}{l}\text { Workshop 2: } \\
\text { Focusing and } \\
\text { planning } \\
\text { 2-day workshop } \\
\text { (12 hours) }\end{array}$ & $\begin{array}{l}\text { Workshop 3: } \\
\text { Aligning/ } \\
\text { mobilising and } \\
\text { inspiring } \\
\text { 2-day workshop } \\
\text { (12 hours) }\end{array}$ & $\begin{array}{c}\text { Seminar: } \\
\text { Presentation of } \\
\text { interprofessional } \\
\text { projects } \\
\text { (5 hours) }\end{array}$ \\
\hline $\begin{array}{l}\frac{n}{0} \\
\frac{\mathfrak{0}}{\circ} \\
\frac{0}{0}\end{array}$ & $\begin{array}{l}\text { - Leading and } \\
\text { managing for } \\
\text { results } \\
\text { - Leading and } \\
\text { managing practices } \\
\text { - Mission \& vision } \\
\text { and creating a } \\
\text { shared vision } \\
\text { - The difference } \\
\text { between a } \\
\text { challenge and a } \\
\text { problem } \\
\text { - Introduction to the } \\
\text { "Challenge Model" } \\
\text { - Tools of scanning } \\
\end{array}$ & $\begin{array}{l}\text { - The Challenge } \\
\text { Model } \\
\text { - Sphere of influence } \\
\text { - Developing } \\
\text { measurable results } \\
\text { with SMART Criteria } \\
\text { - Stakeholder } \\
\text { analysis } \\
\text { - Root cause analysis } \\
\text { - Identify priorities } \\
\text { - Setting priorities } \\
\text { \& conduction of } \\
\text { action plans }\end{array}$ & $\begin{array}{l}\text { - Mobilising } \\
\text { stakeholders } \\
\text { - Developing a } \\
\text { monitoring plan } \\
\text { - Coaching to support } \\
\text { others } \\
\text { - Gaining } \\
\text { commitments } \\
\text { - Roles in teamwork } \\
\text { - Giving feedback } \\
\text { - Making effective } \\
\text { requests } \\
\text { - Inspiring through } \\
\text { building trust } \\
\text { - Leading change }\end{array}$ & $\begin{array}{l}\text { - Presentation of } \\
\text { collaborative } \\
\text { projects } \\
\text { - Evaluation by a } \\
\text { panel of experts }\end{array}$ \\
\hline 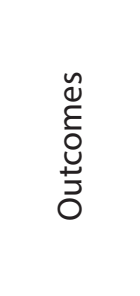 & $\begin{array}{l}\text { Teams are mobilised } \\
\text { to scan their } \\
\text { environment to begin } \\
\text { the change process }\end{array}$ & $\begin{array}{l}\text { Development of the } \\
\text { Challenge } \\
\text { Model for each } \\
\text { interprofessional } \\
\text { team }\end{array}$ & $\begin{array}{l}\text { Completed } \\
\text { Action Plans for each } \\
\text { interprofessional team }\end{array}$ & $\begin{array}{l}\text { Interprofessional } \\
\text { projects developed } \\
\text { to overcome } \\
\text { challenges related } \\
\text { to infection control } \\
\text { in the hospital } \\
\text { departments }\end{array}$ \\
\hline
\end{tabular}


Level 2a in Hammick's model included distribution of the Readiness for Interprofessional Learning Scale (RIPLS) to the participants of the course before and after its conduction. The RIPLS questionnaire assesses change in attitudes and perceptions of students to interprofessional practice (19). This 19item scale is arranged in four main domains; teamwork and collaboration (Items 1-9), negative professional identity (Items 10-12), positive professional identity (Items 14-16), and roles and responsibilities (Items 17-19). The scale has been shown to have good validity and reliability $(19,20)$.

A paper and pencil test consisting of 20 close-ended questions was administered before and after the implementation of the course to assess the acquisition of knowledge in leadership and management (Level 2b). In addition, and since this level also involves acquisition of skills, the evaluation of the projects developed by the interprofessional teams was made by a panel of experts in a final seminar.

As regard, the third level of evaluation (change of behaviour), multisource feedback (360 degree evaluation) was completed by health practitioners working with the course participants, including their supervising physicians, the nurses working in the same wards, and their house officers colleagues who did not share in the study. A 19-item self-administered questionnaire was designed for this purpose and before and after the course in order to assess the change in behaviour. This tool consisted of three main domains; communication skills (7 items), teamwork skills (6 items), and leadership and management skills (6 items). It required ratings by respondents along a five point Likert-type scale.

\section{Data Analysis}

Data was processed using the Statistical Package for Social Sciences (SPSS) Version 20. Descriptive data such as the demographic data and course evaluation were presented in a graphic form. Paired $t$-test was used as a significance test for comparing the pre/post-tests results of assessment of knowledge. The $t$-test was also used to compare the readiness of the study participants for IPE before and after the course, as well as the change in behaviour assessed by the multisource feedback. The $p$ value was considered to be statistically significant at confidence level $95(p<0.05)$.

One-way ANOVA test and Post Hoc test were used for comparing the ratings of the multisource feedback. The differences in the ratings were compared using the mean and standard deviation and the significance of one-way ANOVA, $(p<0.05)$ was considered as the cut-off value for statistical significance.

The study was approved by the research methods committee and the research ethics committee at the Faculty of Medicine in Suez Canal University.

\section{RESULTS}

Evaluation of the participants' satisfaction with the course revealed that more than $85 \%$ of the participants rated the course as "very good". The study participants reported that the course objectives were clearly presented and achieved during the course, and that the course provided them with essential competencies in leadership and management and gave them the opportunity to work and learn from each other.

The results of the study showed statistically significant improvement of the results of the post-measure of RIPLS in all domains for nursing house officers, while they showed statistically significant improvement in the post-measure of RIPLS in three domains only for medical house officers (team work and collaboration, negative professional identify, and positive professional identity) (Table 2). Overall, there was a significant improvement in the post-measure in RIPLS in teamwork and collaboration $(p<0.001)$, positive and negative professional identity 
$(p<0.001)$, roles and responsibilities domain $(p=0.012)$.

The results of the paper and pencil test to assess change in knowledge (Level 2b) showed improvement in house officers' knowledge regarding leadership and management after the implementation of the course. There was a statistically significant difference between the scores of the study group before and after the implementation of the course $(p<0.001)$ (Table 3). The study participants also reported achievement of many project outcomes as a demonstration of acquisition of skills in leadership and management (Level $2 b$ ).

Table 2: Comparison between the responses of study group $(n=38)$ in RIPLS before and after the course using paired $t$-test

\begin{tabular}{|c|c|c|c|c|c|c|}
\hline \multirow{3}{*}{ RIPLS domains } & \multicolumn{3}{|c|}{ Medical house officers } & \multicolumn{3}{|c|}{ Nursing house officers } \\
\hline & \multirow{2}{*}{$\frac{\text { Pre }}{\text { Mean } \pm \text { SD }}$} & \multirow{2}{*}{$\frac{\text { Post }}{\text { Mean } \pm \text { SD }}$} & \multirow{2}{*}{$P$-value } & \multirow{2}{*}{$\frac{\text { Pre }}{\text { Mean } \pm \text { SD }}$} & \multirow{2}{*}{$\frac{\text { Post }}{\text { Mean } \pm \text { SD }}$} & \multirow{2}{*}{$P$-value } \\
\hline & & & & & & \\
\hline $\begin{array}{l}\text { Effective team } \\
\text { working }\end{array}$ & $2.53 \pm 0.641$ & $4.49 \pm 0.208$ & $0.000^{*}$ & $3.01 \pm 0.210$ & $4.72 \pm 0.154$ & $0.000^{*}$ \\
\hline $\begin{array}{l}\text { Relationships } \\
\text { with other } \\
\text { professionals }\end{array}$ & $2.91 \pm 0.738$ & $4.40 \pm 0.412$ & $0.000^{*}$ & $3.12 \pm 0.635$ & $4.66 \pm 0.181$ & $0.000^{*}$ \\
\hline $\begin{array}{l}\text { Negative } \\
\text { professional } \\
\text { identity }\end{array}$ & $3.12 \pm 0.869$ & $1.64 \pm 0.387$ & $0.000^{*}$ & $3.85 \pm 0.947$ & $1.66 \pm 0.181$ & $0.000^{*}$ \\
\hline $\begin{array}{l}\text { Positive } \\
\text { professional } \\
\text { identity }\end{array}$ & $2.72 \pm 0.824$ & $4.18 \pm 0.429$ & $0.000^{*}$ & $2.96 \pm 0.786$ & $4.66 \pm 0.371$ & $0.000^{*}$ \\
\hline $\begin{array}{l}\text { Roles and } \\
\text { responsibilities }\end{array}$ & $3.32 \pm 0.368$ & $3.43 \pm 0.293$ & 0.225 & $3.15 \pm 0.452$ & $3.52 \pm 0.208$ & $0.007^{*}$ \\
\hline
\end{tabular}

Note: *Statistically significant at confidence level $95 \%$.

Table 3: Pre- and post-test scores in the paper and pencil test to assess change in knowledge

\begin{tabular}{lccc}
\hline Group & Pre-test & Post-test & P-Value \\
\cline { 2 - 3 } & Mean \pm SD & Mean \pm SD & \\
\cline { 2 - 3 } $\begin{array}{l}\text { Medical house officers } \\
(\mathrm{n} 1=25)\end{array}$ & $9.80 \pm 2.29$ & $15.08 \pm 2.02$ & $0.000^{*}$ \\
$\begin{array}{l}\text { Nursing house officers } \\
(\mathrm{n} 2=13)\end{array}$ & $11.31 \pm 1.93$ & $16.15 \pm 1.86$ & $0.000^{*}$ \\
$\begin{array}{l}\text { Total } \\
(\mathrm{n}=38)\end{array}$ & $10.32 \pm 2.24$ & $15.45 \pm 1.98$ & $0.000^{*}$ \\
\hline
\end{tabular}

Note: *Statistically significant at confidence level 95\%. 
A significant improvement was found in the participants' "behaviour" in all the tested domains (communication skills, teamwork, leadership and management skills) as reported in the ratings of the doctors, nurses and peers who completed the selfadministered questionnaires based on their observations of the study participants at the workplace. The results of one-way ANOVA for each item in pre/post observation showed that the nurses' responses had higher means in the communication skills, and teamwork, while the colleagues' responses showed the highest mean in the leadership and management skills (Table 4).

The results of the post hoc test to detect the Least Significant Difference (LSD) among groups revealed that there was a significant difference among the responses of colleagues and nurses, and doctors and nurses in communication skills. There was also a significant difference between the responses of colleagues and doctors, and colleagues and nurses in leadership and management skills.

Table 4: Comparison between the responses of the raters in the multisource feedback before and after the course using paired $t$-test

\begin{tabular}{|c|c|c|c|c|c|c|c|c|c|}
\hline \multirow{3}{*}{ Items } & \multicolumn{3}{|c|}{ Doctors } & \multicolumn{3}{|c|}{ Nurses } & \multicolumn{3}{|c|}{ Peer PRHOs } \\
\hline & Pre & Post & & Pre & Post & & Pre & Post & \\
\hline & $\begin{array}{l}\text { Mean } \pm \\
\text { SD }\end{array}$ & $\begin{array}{l}\text { Mean } \pm \\
\text { SD }\end{array}$ & $p$ & $\begin{array}{l}\text { Mean } \pm \\
\text { SD }\end{array}$ & $\begin{array}{c}\text { Mean } \pm \\
\text { SD }\end{array}$ & $p$ & $\begin{array}{l}\text { Mean } \pm \\
\text { SD }\end{array}$ & $\begin{array}{l}\text { Mean } \pm \\
\text { SD }\end{array}$ & $p$ \\
\hline $\begin{array}{l}\text { Communication } \\
\text { skills }\end{array}$ & $\begin{array}{l}2.89 \pm \\
0.324\end{array}$ & $\begin{array}{l}4.21 \pm \\
0.248\end{array}$ & $0.000^{*}$ & $\begin{array}{l}3.93 \pm \\
0.330\end{array}$ & $\begin{array}{l}4.23 \pm \\
0.291\end{array}$ & $0.001^{*}$ & $\begin{array}{l}2.91 \pm \\
0.549\end{array}$ & $\begin{array}{l}4.18 \pm \\
0.311\end{array}$ & $0.000^{*}$ \\
\hline Teamwork & $\begin{array}{l}2.85 \pm \\
0.434\end{array}$ & $\begin{array}{l}4.37 \pm \\
0.322\end{array}$ & $0.000^{*}$ & $\begin{array}{l}3.11 \pm \\
0.429\end{array}$ & $\begin{array}{l}4.40 \pm \\
0.299\end{array}$ & $0.000^{*}$ & $\begin{array}{l}3.04 \pm \\
0.552\end{array}$ & $\begin{array}{l}4.27 \pm \\
0.273\end{array}$ & $0.000^{*}$ \\
\hline $\begin{array}{l}\text { Leadership and } \\
\text { management } \\
\text { skills }\end{array}$ & $\begin{array}{l}2.65 \pm \\
0.507\end{array}$ & $\begin{array}{l}4.03 \pm \\
0.332\end{array}$ & $0.000^{*}$ & $\begin{array}{l}2.89 \pm \\
0.547\end{array}$ & $\begin{array}{l}4.27 \pm \\
0.348\end{array}$ & $0.000^{*}$ & $\begin{array}{l}3.44 \pm \\
0.437\end{array}$ & $\begin{array}{c}4.23 \pm \\
0.278\end{array}$ & $0.000^{*}$ \\
\hline
\end{tabular}

Note: *Statistically significant at confidence level $95 \%$.

\section{DISCUSSION}

Although research on interprofessional education has been reported extensively in the literature internationally, there is only one study on IPE conducted in Egypt on undergraduate students in the Faculty of Medicine, Suez Canal University (13). Therefore, the current study is considered as one of the earliest trials to introduce IPE in health professions education in Egypt.

In this study, we developed an IPE course for medical and nursing pre-registration house officers, in which we adapted a 6-month program in leadership and management; the LDP, a program that is implemented around the world as a framework to face challenges and produce tangible outcomes. IPE usually appears in many forms, such as workshops, courses, and simulation experiences (21). Our choice of conducting the LDP course, adapted from a structured program, was made to facilitate planning and delivering the course within a well-known framework. Leadership and management practices were chosen as the content of the IPE course as they have much in common with the principles of IPE, namely enhanced communication skills, teamwork, and collaboration. Involvement of students in leadership and management has been reported to have a beneficial effect on healthcare delivery and the quality of patient care during actual practice (22).

In this study, the course lasted for two months, which is the duration of one 
training rotation in the pre-registration year, in which a group of house-officers including doctors and nurses are trained in the same department in the university hospital. Our choice of the duration of the course and its delivery in the hospital setting were made to avoid obstacles related to competing time of the house-officers and also to implement the course costeffectively, and with the limited resources we have. All the activities of the course were hands-on, and studying the course produced tangible outcomes, represented in the conduction of collaborative projects by the interprofessional teams. The exposure of our doctors and nurses to this practical experience in IPE was reported by other investigators that it can promote learners' appreciation and value of IPE (23). This was obvious in our study results, in which the readiness for interprofessional learning, with its components; teamwork, positive, and negative professional identities, improved significantly after the conduction of the course.

There exists a debate in the literature whether to introduce IPE pre- or postqualification (24). Some suggest that the most effective IPE might not occur until after graduations, when health professions have to work in real teams to deliver real health care (25), while other prefer early exposure to IPE activities to eliminate hostility stereotyping (24). The reasons for selecting the pre-registration year, in this study, for introduction of IPE course were: it was the first year where teamwork and true collaboration with other professions would take place, it would help house officers identify their roles in the healthcare team, promote their leadership and management skills, and deal with challenges they face at the workplace. We also believe that undergraduate health profession students in the latter years of their study are more likely to have a greater understanding of their clinical identity compared to students in the first years (26). In addition we look forward that this study would contribute to the literature about introducing IPE in the first year of practice for medical and nursing graduates as there is little published evidence on IPE in the context of new medical and nursing graduates in the hospital setting, and the particular issues they face in working for the first time in a multidisciplinary health care team (27).

Evaluations of IPE have in many cases focused on changes in students' attitudes, beliefs and perceptions (28). In this study we followed a published framework for evaluation of educational intervention, specially tailored for IPE (6). We decided to not only assess the outcomes of IPE in terms of change in readiness and attitudes towards interprofessional collaboration, but to go beyond that and assess the outcomes at as many levels as possible; reaction, acquisition of knowledge and skills, and change in behaviour.

In our study, the participants reported that the course allowed them to acquire competencies that would help them better work in interprofessional teams in the future. This finding is supported in a similar study, where students reported competencies associated with acquisition of values and ethics for interprofessional practice, roles/responsibilities, and teams/ teamwork (23).

A systematic review identified RIPLS questionnaire as the most commonly used validated attitudinal instrument in IPE (29). Usage of this validated tool in our study was important to measure the change of attitudes of the participants towards interprofessional collaboration which represents one of the key learning outcomes for IPE interventions (1). In common with other studies that compared the readiness for interprofessional learning before and after conducting interprofessional modules/courses, the readiness for interprofessional education in our study improved after course delivery. Those studies varied between conducting monthly interprofessional modules for undergraduate students (26), a one credit interprofessional module for undergraduate students (30), 
and a one-day workshop involving students from more than four health professions institutions (31). All the three previous studies reported improvement in the postRIPLS measures.

It was reported that the assessment of learners' behaviours in teams is important and most effective when conducted in the workplace (25). Some studies indicated change in behaviour as a result of IPE (32, $33,34)$. However, this change was mainly self-reported perception of change, which may be a weak approach to measuring change in behaviour (35). Therefore, we did not rely solely on the learners' self-reports, and we assessed the change in collaborative behaviour and leadership and management practices by multisource feedback at the workplace, in addition to evaluation of the projects developed by the interprofessional teams. This approach can contribute to future directions for evaluating IPE initiatives (36).

Limitations to the current study include not going beyond the third level of evaluation of educational intervention to assess organisational change or patient outcomes. Also, the fact that the LDP program was adapted to be delivered in a shorter period than originally planned leads to difficulty in comparing the outcomes of the course to the work of others who implemented the full program. An additional limitation in the study was the validation of the tool used for multisource feedback, which was developed by the researchers. This tool was tested for face and content validity only, so further indepth construct validation will be needed if this instrument is to be used in future research.

\section{CONCLUSION}

Introducing training on leadership and management in an interprofessional context for pre-registration house officers of different professions promoted their competencies both in IPE and leadership and management and provided them with a good opportunity to learn with and from each other, as well as improved their behaviour at the workplace. Our results indicated opportunities for conducting IPE courses within structured frameworks and limited resources. These results can encourage other health profession institutes to apply IPE in different settings.

\section{ACKNOWLEDGEMENTS}

The authors wish to acknowledge the efforts of the members of the paediatrics and the gynaecology and obstetrics departments for facilitating the implementation of the participants' projects. They also wish to acknowledge the efforts of the LDP trainers who shared in the course.

\section{REFERENCES}

1. Barr H, Koppel I, Reeves S, Hammick M, Freeth D. Effective interprofessional education: argument, assumption and evidence. Oxford, UK: Blackwell Publishing Ltd; 2005.

2. World Health Organization (WHO). Framework for action on interprofessional education and collaborative practice. Geneva: World Health Organization; 2010.

3. Barr H. Working together to learn together: learning together to work together. Journal of Interprofessional Care. 2000;14(2):177-9. https://doi.org/10.1080/jic.14.2.177.179

4. Liaison Committee on Medical Education (LCME). Public Hearing on Proposed New Accreditation Standard ED-19-A; Rationale for creation of accreditation standard ED-19-A. AAMC Annual Meeting. San Francisco, CA; 2012.

5. Leathard A. Interprofessional collaboration: from policy to practice in health and social care. Hove and New York: BrunnerRoutledge; 2003. 
6. Hammick M. Interprofessional education: evidence from the past to guide the future. Journal of Medical Teacher. 2000;22(2):461-7. https://doi. org/10.1080/01421590050110713

7. Kirkpatrick DL. Evaluating training programs: the four levels. San Francisco: Berrett-Koehler; 1994.

8. Hean S, Craddock D, Hammick $M$. Theoretical insights into interprofessional education: AMEE Guide No. 62. Medical Teacher. 2012;34:e78-101. https://doi.org/10 $.3109 / 0142159 X .2012 .643263$

9. Department of Health and QAA. Department of health phase 2 benchmarking project-final report. London: Department of Health; Gloucester: Quality Assurance Agency for Higher Education; 2006.

10. Department of Health and Ageing. Towards a national primary health care strategy. Canberra: Department of Health and Ageing; 2008.

11. Australasian Interprofessional Practice and Education Network. About-AIPPEN. 2010 [cited 2004 December 29]. Available from: http://www.aippen.net/about-aippen

12. Canadian Interprofessional Health Collaborative. Situational analysis: current state of interprofessional education (IPE) in Canada. Canada: College of Health Disciplines University of British Columbia Vancouver; 2008 [cited 2016 November 15]. http://www.cihc.ca/files/CIHC_ SituationalAnalysisIPE_May2008_Final.pdf

13. Hosny S, Kamel MH, El-Wazir Y, Gilbert J. Integrating interprofessional education in community-based learning activities: case study. Medical Teacher Journal. 2013;35:68$73 . \quad$ https://doi.org/10.3109/014215 9X.2013.765550

14. Badrawi N, Hosni S, Rashwan M. National Academic Reference Standards (NARS): Medical (Draft). 2nd ed. Egypt: National Authority for Quality Assurance and Accreditation in Education (NAQAAE); 2017.
15. Richman RC, Morahan PS, Cohen DW, McDade SA. 2001. Advancing women and closing the leadership gap: the executive leadership in academic medicine (ELAM) program experience. Journal of Women's Health. 12:111-14. https:/doi. org/10.1089/152460901300140022

16. Mosley DC, Megginson LC, Pietri PH. Supervisory management: the art of inspiring, empowering, and developing people. 6th ed. Cengage Learning, USA: South Western, Thomson; 2005. p. 6-11.

17. Galer JB, Vriesendorp S, Ellis A. Managers who lead: a handbook for improving health services. Cambridge, Massachusetts: Management Sciences for Health; 2005. p. 6-25.

18. Management Sciences for Health. Leadership development program: facilitator's guide. 2009 [cited 2016 December 20]. https://www.msh.org/ resources/leadership-development-programplus-ldp-a-guide-for-facilitators- 0

19. McFadyen AK, Webster VS, Maclaren WM. The test-retest reliability of a revised version of the Readiness for Interprofessional Learning Scale (RIPLS). Journal of Interprofessional Care. 2006;20(6):633-9.

20. Parsell G, Bligh J. The development of a questionnaire to assess the readiness of health care students for Interprofessional Learning (RIPLS). Journal of Medical Education. 1999; 33:95-100. https://doi. org/10.1046/j.1365-2923.1999.00298.x

21. Abu-Rish E, Kim S, Choe L, Varpio L, Malik E, White AA, Craddick K, Blondon K, Robins L, Nagasawa P, Thigpen A, Chen LL, Rich J, Zierler B. Current trends in interprofessional education of health sciences students: A literature review. Journal of Interprofessional Care. 2012;26(6):44451. https://doi.org/10.3109/13561820.2012. 715604 
22. Ladhani Z, Scherpbier AJ, Stevens FJ. Competencies for undergraduate community based education for the health professions: a systematic review. Medical Teacher Journal. 2012; 39:733-43. https://doi.org/10.3109/01 42159X.2012.700742

23. Blue A, Mitcham M, Koutalos Y, Howell D, Leaphart A. Attaining interprofessional competencies through a student interprofessional fellowship program. Journal of Interprofessional Care. 2015;29(3):253-5. https://doi.org/10.3109/13561820.2014.954 283

24. Graham J, Wealthall S. Interdisciplinary education for the health professions: taking the risk for community gain. Focus on Health Professional Education Journal. 1999;1:49-69.

25. Hays R. Interprofessional education. The Clinical Teacher. 2013;10:338-41. https:// doi.org/10.1111/tct.12115

26. Wakely L, Brown L, Burrows J. Evaluating interprofessional learning modules: health students' attitude to interprofessional practice. Journal of Interprofessional Care. 2013; 27(5):424-5. https://doi.org/10.3109/1 3561820.2013 .784730

27. Weller JM, Barrow M, Gasquoine S. Interprofessional collaboration among junior doctors and nurses in the hospital setting. Medical Education. 2011;45:478-87. https:// doi.org/10.1111/j.1365-2923.2010.03919.x

28. Hean S, Clark JM, Adams K, Humphris D. Will opposites attract? Similarities and differences in students' perceptions of the stereotype profiles of other health and social care professional groups. Journal of Interprofessional Care. 2006;20:162-181. https://doi.org/10.1080/13561820600646546

29. Thistlethwaite J, Kumar K, Moran M, Saunders R, Carr S. An exploratory review of pre-qualification interprofessional education evaluations. Journal of Interprofessional Care. 2015;29(4):292-7. https:/doi.org/10.3109/13561820.2014.985 292
30. Ruebling I, Pole D, Breitback AP, Fragr A, Kettenbach G, Westhus N, Kienstra $\mathrm{K}$, Carlson J. A comparison of student attitudes and perceptions before and after an introductory interprofessional education experience. Journal of Interprofessional Care. 2014;28(1):23-7. https://doi.org/10.31 $09 / 13561820.2013 .829421$

31. Hadjistavropoulos HD, Juckes K, Dirkse D, Cuddington C, Walker K, Bruno P, White G, Ruda L, Pitzel BM. Student evaluations of an interprofessional education experience in pain management. Journal of Interprofessional Care. 2015;29(1):73-5. https://doi.org/10.3109/13561820.2014.917 613

32. Morey JC, Simon R, Jay GD, Wears RL, Salisbury M, Dukes KA, Berns SD. Error reduction and performance improvement in the emergency department through formal teamwork training: evaluation results of the med teams project. Health Service Res. 2002;37:1553-81. https://doi. org/10.1111/1475-6773.01104

33. Morison S, Boohan M, Jenkins J, Moutray M. Facilitating under- graduate interprofessional learning in healthcare: comparing classroom and clinical learning for nursing and medical students. Learn Health Soc Care. 2003;2:92-104. https://doi. org/10.1046/j.1473-6861.2003.00043.x

34. Pollard K, Miers M, Gilchrist M. Second year skepticism: pre-qualifying health and social care students' midpoint selfassessment, attitudes and perceptions concerning interprofessional learning and working. Journal of Interprofessional Care. 2005; 19(3):251-68. https://doi. org/10.1080/13561820400024225

35. Hammick M, Freeth D, Koppel I, Reeves S, Barr H. A best evidence systematic review of interprofessional education: BEME Guide no. 9. Medical Teacher. 2007;29:735-51. https://doi.org/10.1080/01421590701682576 
36. Reeves S, Boet S, Zierler B, Kitto S. Interprofessional education and practice guide no. 3: evaluating interprofessional education. Journal of Interprofessional Carer. 2015;29(4):305-312. https://doi.org/1 $0.3109 / 13561820.2014 .1003637$ 